\title{
WPEYW INFORMACJI O PLANOWANEJ FORMIE EDUKACJI NA EMOCJE I POZIOM STRESU WŚRÓD STUDENTÓW
}

\author{
Natalia Serwan (autor korespondencyjny) \\ Instytut Psychologii, Wydział Nauk Społecznych, Uniwersytet Opolski \\ ul. Plac Staszica 1, 45-052 Opole \\ E-mail: natalia.serwan.uni.opole@gmail.com \\ ORCID: https://orcid.org/0000-0003-4979-7105 \\ Martyna Gdowska \\ Instytut Psychologii, Wydział Nauk Społecznych, Uniwersytet Opolski \\ ul. Plac Staszica 1, 45-052 Opole \\ E-mail: martyna.gdowska.uni.opole@gmail.com \\ ORCID: https://orcid.org/0000-0003-0057-5704 \\ Magdalena Matusiak \\ Instytut Psychologii, Wydział Nauk Społecznych, Uniwersytet Opolski \\ ul. Plac Staszica 1, 45-052 Opole \\ E-mail: magdalena.matusiak.uni.opole@gmail.com \\ ORCID: https://orcid.org/0000-0002-3128-8241 \\ Julia Raywer \\ Instytut Psychologii, Wydział Nauk Społecznych, Uniwersytet Opolski \\ ul. Plac Staszica 1, 45-052 Opole \\ E-mail: 127437@student.uni.opole.pl \\ ORCID: https://orcid.org/0000-0002-7424-5639 \\ Anna Wojtkowska \\ Instytut Psychologii Uniwersytetu SWPS we Wrocławiu, \\ Wydział Nauk Społecznych Uniwersytetu Opolskiego, \\ Fundacja Badań Społecznych w Szczecinie \\ E-mail: a.starkowska.pum@gmail.com \\ ORCID: https://orcid.org/0000-0002-0613-622X
}

\section{Abstrakt}

Cel badań. Głównym celem badania było określenie zmian subiektywnej oceny wybranych stanów afektywnych wśród studentów, które zachodziły na skutek przekazania tej grupie dwóch różnych informacji o terminie zakończenia nauki zdalnej oraz o powrocie do stacjonarnego trybu studiów. 
Metoda i materiały. Na podstawie ankiet wypełnianych przez studentów, dokonano pomiaru nasilenia deklarowanych afektów negatywnych i stresu. Zawarto w nich również sfałszowane oświadczenie Ministra Nauki i Szkolnictwa Wyższego, dotyczące rzekomego powrotu badanych na uczelnię lub wciąż aktualnej niemożności wznowienia nauki w trybie stacjonarnym. Badanie przeprowadzono w modelu eksperymentalnym.

Wyniki. Po pierwszym semestrze zdalnego nauczania nie było jasnej odpowiedzi emocjonalnej studentów, świadczącej o obiektywnej słuszności któregoś z możliwych wyborów - kontynuowania nauki zdalnej bądź wznowienia nauczania stacjonarnego. Wyniki wskazują jednak, że w związku z podaniem informacji o powrocie do stacjonarnego trybu nauczania, u studentów zmalała bezradność, za to wzrósł niepokój.

Wnioski. Ambiwalentna odpowiedź emocjonalna, odnotowana wśród osób poinformowanych o zakończeniu nauczania zdalnego, może być uwarunkowana zarówno ekspozycją na rzetelną informację dotyczącą formy studiowania w przyszłym semestrze - co wyjaśniałoby spadek bezradności - jak również zaistnieniem realnego zagrożenia zachorowania na COVID-19 po wznowieniu edukacji stacjonarnej na uczelniach wyższych - a to z kolei może być czynnikiem indukującym wzrost niepokoju. Wyniki zachęcają do kontynuacji badań nad postrzeganiem zdalnego nauczania jako efektywnej formy ochrony studentów przed negatywnymi skutkami COVID-19. Słowa kluczowe: COVID-19, studenci, negatywne emocje, stres, edukacja zdalna.

The impact of information about the planned form of education on the negative emotions and stress levels of university students

\section{Abstract}

Aim. The main objective of this study was to determine changes in the subjective assessment of selected affective states among students, as a result of providing them with two different sets of information about the date of finishing e-learning and returning to the full-time study

Method and materials. On the basis of the questionnaires completed by students, the intensity of the declared negative affect and stress was measured. They also contained a false statement of the (Polish) Minister of Science and Higher Education regarding the alleged return of the respondents to the university or the still current impossibility of resuming studies in the full-time mode. The study was conducted in an experimental model.

Results. After the first semester of e-learning, there was no clear emotional response from students that would prove the objective rightness of one of the possible choices continuing e-learning or resuming full-time learning. However, the results indicate that in connection with the information about returning to the full-time teaching mode, the helplessness of students decreased, but the anxiety increased.

Conclusions. The ambivalent emotional response noted among people informed about the end of e-learning may be conditioned both by exposure to reliable information about the form of education in the next semester - which would explain the decrease in helplessness - as well as the real risk of developing COVID-19 after returning to the full-time study mode - and this, in turn, may be a factor in increasing anxiety. The results encourage the 
continuation of research on the perception of e-learning as an effective way of protecting students from the negative effects of COVID-19.

Key words: COVID-19, students, negative emotions, stress, e-learning.

\section{WPROWADZENIE}

Zagrożenie epidemiologiczne związane z pandemią koronawirusa SARS-CoV-2 wymusiło zmianę dotychczasowej formy edukacji (Rozporządzenie Ministra Nauki i Szkolnictwa Wyższego z dnia 11 marca 2020r.). Zgodnie z wytycznymi, niemal wszystkie placówki edukacyjne zostały zobowiązane do przejścia ze stacjonarnego trybu nauczania na edukację zdalną. Większość krajów nie była przygotowana na tak nagłą zmianę formy kształcenia, przez co problemy związane $\mathrm{z}$ jego organizacją sprawiły, że uczniowie, nauczyciele, jak i studenci odczuwali negatywne emocje oraz znajdowali się pod wpływem dużego stresu (Yehudai i in., 2020).

Grupami szczególnie narażonymi na stres okazały się kobiety, ludzie młodzi oraz osoby odczuwające mniej pozytywnych emocji (Bell $\mathrm{i}$ in., 2020; Cao i in., 2020). Według badań, nawet jedna trzecia studentów doświadczyła lęku podczas trwania pandemii COVID-19 (Cao i in., 2020), a wdrożenie e-learningu mogło go nawet nasilać. Ponadto, odczuwany stres mógł być związany z obawą o zaliczenie roku akademickiego (Hasan, Bao, 2020) jako, że odbywać się ono miało w dotąd nieznanej studentom formie. Nieobecność zajęć stacjonarnych poskutkowała częstymi rezygnacjami z wynajmowanych stancji. Uwidoczniło się to szczególnie wśród osób uczących się dziennie. Wiele z nich wróciło w rodzinne strony. Co ciekawe, studenci, którzy przeprowadzili się do rodziców $\mathrm{w}$ okresie pandemii, charakteryzowali się obniżonym poziomem stresu w porównaniu do tych, którzy mieszkali na stancji (Marelli, 2020). Również zamieszkiwanie obszarów miejskich okazało się czynnikiem chroniącym przed doświadczaniem lęku, natomiast wśród osób mieszkających samotnie czy w małych miejscowościach, mógł być on wyższy (Huang, Zhao, 2020; Cao i in., 2020). Warto podkreślić też, że posiadanie bliskich lub znajomych zakażonych koronawirusem także przyczyniało się do zwiększenia niepokoju (Cao i in., 2020). Co czwarty student doświadczał nasilonych objawów depresyjnych. Ci zaś, którzy twierdzili, że kwarantanna może wpłynąć negatywnie na ich zdrowie psychiczne, częściej doświadczali symptomów depresyjnych. Tylko niewielki odsetek studentów uważa, że COVID-19 nie wywoła u nich problemów zdrowotnych (Mechili i in., 2020).

Na postrzeganie przez studenta nauczania jako satysfakcjonującego mają wpływ interakcje z prowadzącym, $\mathrm{w}$ tym odpowiedzi na czas i informacja zwrotna. W porównaniu do nauczania stacjonarnego, w nauczaniu zdalnym może brakować wyżej wymienionych czynników, dlatego szczególnie ważna w odczuwaniu satysfakcji z e-learningu jest responsywność wykładowcy i pozostawanie z nim w dialogu. Ponadto, duże znaczenie ma również jakość połączenia z internetem. Prawdopodobnie, niespełnienie powyższych warunków skutkowało negatywnym ocenianiem zdalnego nauczania przez studentów (Abbasi, Ayoob, Malik, Memon, 2020). Badania Marion Händel i in. (2020) wykazały jednak, że studenci wysoko oceniali swoje umiejętności dotyczące korzystania z e-learningu, a ponadto ci, którzy dysponowali odpowiednimi narzędziami do takiego nauczania (dostęp do sprzętu elektronicznego i związanych z nim akcesoriów, jakość połączenia z Internetem czy umiejętności posługiwania się konkretną platformą komu- 
nikacyjna, na której odbywają się zajęcia) odczuwali mniejsze napięcie i przeciążenie, czuli się mniej zmartwieni, osamotnieni, a tym samym doświadczali większej radości i korzystniej oceniali swój work-life balance. Z kolei niektórzy studenci dystansowali się względem zdalnego nauczania przez brak połączenia sieciowego oraz problemy techniczne i finansowe. Dodatkowymi wyzwaniami okazały się także problemy związane $\mathrm{z}$ pracą $\mathrm{w}$ grupach czy długi czas oczekiwania na odpowiedzi prowadzących. (Adarkwah, 2020; Adnan, Anwar, 2020). Bardzo często komunikatory internetowe, zapewniane przez uczelnie, okazywały się niewystarczajace do udźwignięcia naporu danych. Warto również nadmienić, że z początku jedyną formą sprawdzenia wiedzy studenta było wykonywanie zadań na czas, których mnogość wpłynęła zarówno na punktualność ich odsyłania jak i szybkość otrzymywania informacji zwrotnej od prowadzących.

\section{Cel badania}

Przewodnim celem badania było określenie zmian subiektywnej oceny wybranych stanów afektywnych wśród studentów, zachodzących na skutek przekazania tej grupie dwóch różnych informacji o terminie zakończenia nauki zdalnej oraz o powrocie do stacjonarnego trybu studiów.

Ponadto, badanie sprawdzało możliwe powiązania pomiędzy deklarowanymi odczuciami względem przyszłej formy studiowania a dodatkowymi czynnikami socjodemograficznymi - płcia, wiekiem, wielkością miejsca zamieszkania oraz znajdowaniem się w grupie podwyższonego ryzyka ciężkiego przebiegu COVID-19. Główna hipoteza badawcza dotyczyła założenia, że rodzaj podanej informacji o przyszłej formie kształcenia będzie różnicował zmiany w subiektywnej ocenie wybranych stanów emocjonalnych wśród studentów; oczekiwano, że osoby poinformowane o powrocie do stacjonarnego trybu zajęć odczują negatywne zmiany powiązane z większym deklarowanym stresem i obawami przed zakończeniem zdalnej edukacji. Hipoteza dodatkowa zakładała, że niektóre charakterystyki studentów mogą różnicować ich postrzegane stany emocjonalne - przypuszczano, że większym nasileniem negatywnych afektów cechować będą się kobiety, osoby młodsze, pochodzące z małych miejscowości i bardziej narażone na doświadczenie poważnych powikłań COVID-19.

\section{Metoda}

\section{Materiaty i procedura}

Badanie przeprowadzono za pomocą ankiety online, stworzonej za pomocą Formularza Google. Link do ankiety był rozpowszechniany na Facebook'u oraz na Instagramie. Dane zbierano w dniach od 16 czerwca 2020 roku do 22 czerwca 2020 roku.

Zestaw ankietowy został poprzedzony instrukcją w której opisany został ogólny cel badania, jego przeznaczenie, dane o autorach badania wraz z kontaktem mailowym oraz informacje o całkowitej anonimowości i dobrowolności udziału. W pierwszej części ankiety zapytano o podstawowe dane socjodemograficzne (wiek, płeć, wielkość miejsca zamieszkania) oraz te dotyczące województwa, w którym studiują ankietowani. Następnie umieszczono pytania związane z najbliższą sesją egzaminacyjna, takie jak: „W jakiej formie studiujesz?", ,'W jakiej formie zdajesz najbliższą sesję egzaminacyjną?", "Jak uważasz, w jakiej formie powinna odbyć się najbliższa sesja egzaminacyjna?". W kolejnej części badani mieli określić aktualny, subiektywnie postrzegany poziom 
stresu, mający związek z sesją egzaminacyjną. Nasilenie stresu badani określali na skali od 1 (zdecydowanie niższy niż zwykle) do 7 (zdecydowanie wyższy niż zwykle). W następnej kolejności umieszczono zestaw pytań, odnoszących się do stopnia ryzyka zachorowania na COVID-19, takich jak: „Czy jesteś w grupie podwyższonego ryzyka zachorowania na COVID-19 (choroby przewlekłe wspótistniejące)?”, ",Czy ktoś Tobie bliski jest w grupie podwyższonego ryzyka zachorowania na COVID-19?”, ,"Czy ktoś z Twojego najbliższego otoczenia (rodzina, znajomi) zachorował lub podejrzewał, że chorował na COVID-19?". W kolejnej części znajdowały się pytania o deklarowany poziom emocji, związanych $\mathrm{z}$ potencjalnym powrotem na uczelnię $\mathrm{w}$ przyszłym semestrze, czyli od października 2020 roku. Zapytano o ogólny poziom stresu, bezradności, poczucia bezpieczeństwa, lęku, o nasilenie niepokoju, poziom smutku, nasilenie obaw o zarażenie koronawirusem po wznowieniu stacjonarnego nauczania, i o to, czy sam powrót na uczelnię jest zdarzeniem pozytywnym oraz o poczucie skuteczności własnej pracy po przywróceniu stacjonarnej formy nauczania. Osoby badane określały nasilenie tych odczuć, korzystając ze skali od 1 (najmniejsze nasilenie emocji) do 5 (największe nasilenie emocji). Następnie zaprezentowano jedną z dwóch wersji sfalsyfikowanego oświadczenia Ministerstwa Edukacji i Szkolnictwa Wyższego (Załączniki 1 i 2). Dokument został przygotowany specjalnie na potrzeby tego badania. $\mathrm{W}$ oparciu o prawdziwe rozporządzenie Ministra Nauki i Szkolnictwa Wyższego z dnia 21 maja 2020 r. w sprawie czasowego ograniczenia funkcjonowania niektórych podmiotów systemu szkolnictwa wyższego i nauki w związku z zapobieganiem, przeciwdziałaniem i zwalczaniem COVID-19, zamieszczone na stronie wspomnianego organu (Rozporządzenie Ministra Nauki i Szkolnictwa Wyższego z dnia 21 maja 2020 r.) opracowano fałszywe oświadczenie, informujące o powrocie do stacjonarnej formy nauczania na uczelniach wyższych od października 2020 roku oraz drugie, o kontynuacji nauczania zdalnego w październiku 2020 roku. Oświadczenie stworzono w programie Microsoft Word 2010, samą treść przepisano i zmodyfikowano przy pomocy czcionki Times New Roman, która wizualnie jest zbliżona do tej użytej w oryginalnym oświadczeniu. Logotyp oraz nagłówek rozporządzenia skopiowano $\mathrm{z}$ oryginalnego tekstu oraz zmodyfikowano $\mathrm{w}$ programie graficznym, w celu zmiany daty wydania rozporządzenia. Usunięto również jedną literę z nazwiska osoby podpisanej na rozporządzeniu. W samej treści oświadczenia zmodyfikowano nazwę organu państwowego na "Minister Edukacji i Szkolnictwa Wyższego" oraz zmieniono inicjały Ministra z „W. Murdzek" na „M. Wurdzek”.

Osobom badanym losowo prezentowano jedną z wersji ankiety; w ten sposób dwóm grupom badanym zostały przekazane różne informacje o potencjalnie podobnej wiarygodności. Następnie w obu grupach następował drugi pomiar odczuć w oparciu o identyczny zestaw pytań, który dostępny był przed prezentacją oświadczenia. W instrukcji do drugiego pomiaru poproszono, aby ocenić swoje aktualne, subiektywnie postrzegane afekty zaraz po odczytaniu oświadczeń.

W zakończeniu każdej ankiety informowano badanych o nieprawdziwości przedstawionego im rozporządzenia.

\section{Grupa badana}

W badaniu wzięło udział 296 studentów, z przewagą kobiet (82,4\%) w wieku od 18 do 29 lat. W tabeli 1. podano dokładną charakterystykę grupy pod względem danych 
socjodemograficznych $\mathrm{i}$ tych dotyczących formy studiowania, preferowanej formy sesji egzaminacyjnej, występowania podwyższonego ryzyka zachorowania na COVID-19 oraz przypadków zakażenia wśród badanych studentów lub ich bliskich. W ankietowanej grupie dominowały osoby studiujące dziennie (prawie 92\%). Dokładnie połowa uczestników pochodziła ze wsi i najmniejszych miast, a ponad 77\% preferowała zdawanie najbliższej sesji egzaminacyjnej w trybie całkowicie zdalnym. Łącznie $14,2 \%$ badanych zadeklarowało, że należy do grupy podwyższonego ryzyka zachorowania na COVID-19, a 64,5\% przyznało, że wśród ich najbliższych znajdują się osoby o podwyższonym ryzyku. Średnio co piąty uczestnik informował, że w jego najbliższym otoczeniu wystąpiły przypadki zachorowania lub ryzyka zachorowania na COVID-19.

W tabeli 1. podano dane statystyczne zarówno dla całej badanej grupy, jak i dwóch porównywanych podgrup, które otrzymały inne informacje o terminie powrotu na uczelnię. Podgrupy te nie różniły się istotnie rozkładem płci oraz występowaniem podwyższonego ryzyka zachorowania na COVID-19 wśród badanych i ich bliskich ( $p>0,05)$. Odnotowano natomiast $\mathrm{w}$ pełni istotne różnice $\mathrm{w}$ wieku, wielkości miejsca zamieszkania i formie studiów $(\mathrm{p}<0,05)$ - wśród osób informowanych o powrocie na uczelnię było więcej osób starszych, pochodzących z większych miejscowości i studiujących zaocznie.

Tabela 1

Charakterystyka badanej próby osób ( $N=296)$

\begin{tabular}{|c|c|c|c|c|c|c|}
\hline \multirow[t]{2}{*}{ Zmienne } & \multirow{2}{*}{$\begin{array}{c}\begin{array}{c}\text { Cała grupa, } \\
\mathrm{N}=296\end{array} \\
M(S D) / N(\%)\end{array}$} & \multirow{2}{*}{$\begin{array}{c}\text { Nie wracamy, } \\
\mathrm{n}=147\end{array}$} & \multirow{2}{*}{$\begin{array}{c}\begin{array}{c}\text { Wracamy, } \\
\mathrm{n}=149\end{array} \\
M(S D) / n(\%)\end{array}$} & \multicolumn{3}{|c|}{ Porównanie grup } \\
\hline & & & & $X 2 / Z$ & $d f$ & $p$ \\
\hline \multicolumn{7}{|l|}{ Płeć } \\
\hline kobiety & $243(82,4 \%)$ & $120(82,2 \%)$ & $123(82,6 \%)$ & & & \\
\hline mężczyźni & $52(17,6 \%)$ & $26(17,8 \%)$ & $26(17,4 \%)$ & 0,007 & 1 & 0,936 \\
\hline Wiek & $21,30(1,87)$ & $20,30(1,29)$ & $22,30(1,82)$ & $-9,919$ & - & $<0,001$ \\
\hline \multicolumn{7}{|c|}{ Miejsce zamieszkania } \\
\hline wieś & $80(27,0 \%)$ & $50(34,0 \%)$ & $30(20,1 \%)$ & 22,446 & 5 & $<0,001$ \\
\hline $\begin{array}{l}\text { miasto do } 50 \text { tys. } \\
\text { mieszkańców }\end{array}$ & $68(23,0 \%)$ & $41(27,9 \%)$ & $27(18,1 \%)$ & & & \\
\hline $\begin{array}{l}\text { miasto liczące } \\
\text { 50-150 tys. } \\
\text { mieszkańców } \\
\text { miasto liczące }\end{array}$ & $47(15,9 \%)$ & $24(16,3 \%)$ & $23(15,4 \%)$ & & & \\
\hline $\begin{array}{l}\text { 150-250 tys. } \\
\text { mieszkańców } \\
\text { miasto liczace }\end{array}$ & $26(8,8 \%)$ & $8(5,4 \%)$ & $18(12,1 \%)$ & & & \\
\hline $\begin{array}{l}250-500 \text { tys. } \\
\text { mieszkańców } \\
\text { miasto liczące } \\
\text { powyżej } 500 \text { tys. } \\
\text { mieszkańców }\end{array}$ & $22(7,4 \%)$ & $15(10,2 \%)$ & $13(8,7 \%)$ & & & \\
\hline
\end{tabular}




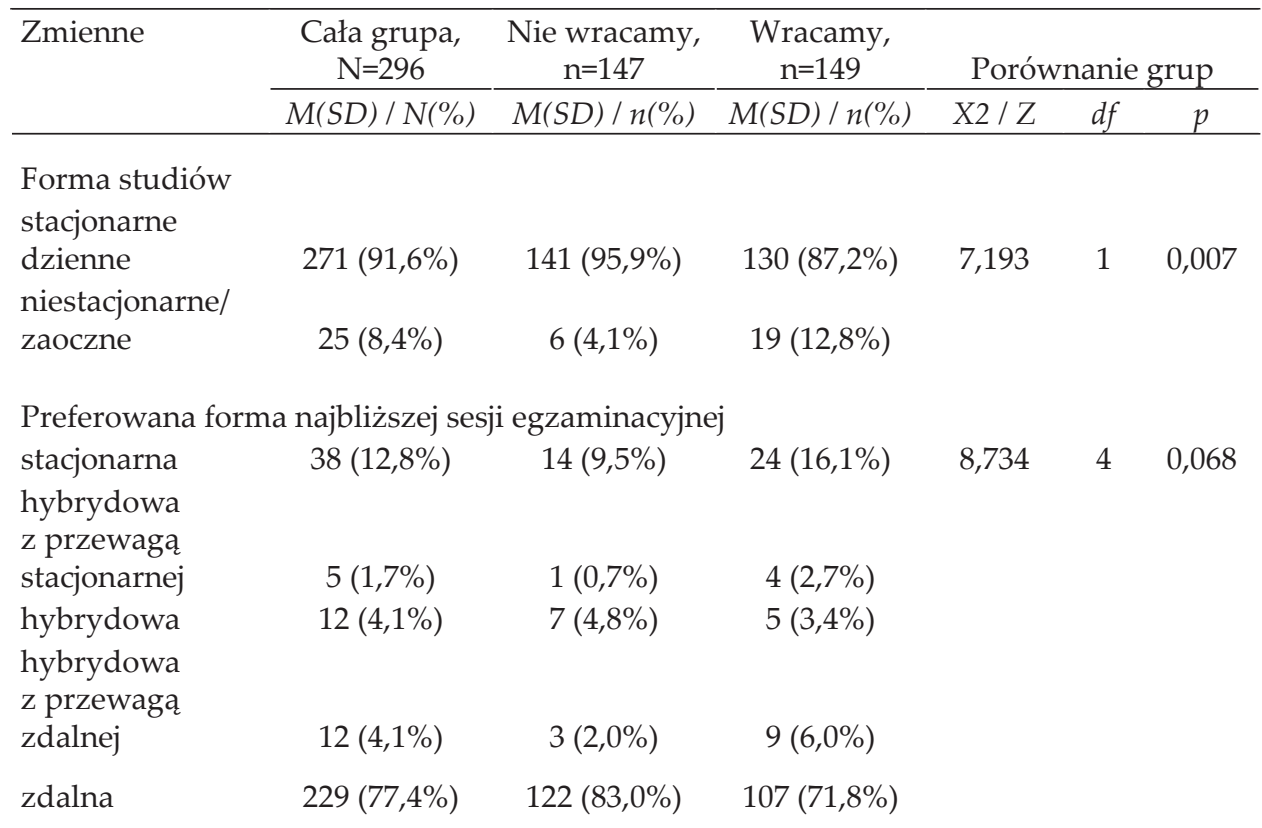

Czy jesteś w grupie podwyższonego ryzyka zachorowania na COVID-19? zdecydowanie nie jestem

$\begin{array}{cccccc}166(56,1 \%) & 83(56,5 \%) & 83(55,7 \%) & 0,435 & 4 & 0,980 \\ 60(20,3 \%) & 28(19,0 \%) & 32(21,5 \%) & & & \\ 28(9,5 \%) & 14(9,5 \%) & 14(9,4 \%) & & \\ 22(7,4 \%) & 12(8,2 \%) & 10(6,7 \%) & & \\ 20(6,8 \%) & 10(6,8 \%) & 10(6,7 \%) & & \end{array}$
nie jestem nie wiem jestem zdecydowanie jestem $20(6,8 \%) \quad 10(6,8 \%) \quad 10(6,7 \%)$

Czy ktoś Tobie bliski jest w grupie podwyższonego ryzyka zachorowania na COVID-19?

zdecydowanie

$\begin{array}{llll}\text { nie jest } & 36(12,2 \%) & 20(13,6 \%) & 16(10,7 \%) \\ \text { nie jest } & 33(11,1 \%) & 18(12,2 \%) & 15(10,1 \%) \\ \text { nie wiem } & 36(12,2 \%) & 21(14,3 \%) & 15(10,1 \%) \\ \text { jest } & 58(19,6 \%) & 26(17,7 \%) & 32(21,5 \%) \\ \text { zdecydowanie } & & & \\ \text { jest } & 133(44,9 \%) & 62(42,2 \%) & 71(47,7 \%)\end{array}$

Czy ktoś z Twojego najbliższego otoczenia zachorował lub był podejrzany o zachorowanie na COVID-19?

\begin{tabular}{lcccccc} 
tak & $62(20,9 \%)$ & $37(25,2 \%)$ & $25(16,8 \%)$ & 4,979 & 2 & 0,083 \\
nie & $207(69,9 \%)$ & $94(63,9 \%)$ & $113(75,8 \%)$ & & & \\
nie wiem & $27(9,1 \%)$ & $16(10,9 \%)$ & $11(7,4 \%)$ & & & \\
\hline
\end{tabular}

Źródto: badanie własne autorów. 


\begin{abstract}
Analiza statystyczna
Zgromadzone dane poddano ilościowej analizie statystycznej przy użyciu pakietu IBM SPSS Statistics v.25. Różnice międzygrupowe w ocenie poszczególnych, postrzeganych przez osoby badane stanów emocjonalnych w pierwszym i drugim pomiarze sprawdzono dwoma sposobami. Różnice w rozkładach częstotliwości występowania określonych kategorii zmiennych jakościowych weryfikowano testem chi-kwadrat Pearsona, zaś różnice w przeciętnym nasileniu cech ilościowych - nieparametrycznym testem U Manna-Whitney'a dla grup niezależnych. W następnej kolejności różnice wewnątrzgrupowe, mogące świadczyć o zmianach w ocenie stanów emocjonalnych $\mathrm{w}$ odpowiedzi na otrzymaną wiadomość, sprawdzono testem Wilcoxona dla dwóch grup zależnych. Dodatkowe założenia o relacjach między subiektywnymi odczuciami studentów a cechami socjodemograficznymi, sprawdzano współczynnikiem korelacji Spearmana oraz testami U Manna-Whitney'a i Kruskala-Wallisa.

Wybrano metody nieparametryczne ze względu na znaczne różnice między empirycznymi rozkładami cech ciagłych a rozkładem normalnym (zarówno w analizie podgrup testem Kołmogorowa-Smirnowa, jak i całej próby testem Shapiro-Wilka wartość statystyki była zawsze bliska zeru; $\mathrm{p}<0,001)$. Za wskaźnik istotności statystycznej przyjęto wartość $\mathrm{p}<0,05$.
\end{abstract}

\title{
WYNIKI
}

W tabeli 2. przedstawiono wyniki pierwszego pomiaru afektów, przed prezentacją informacji o terminie powrotu na uczelnię. Wykazano średnie (M) i odchylenie standardowe (SD) tak dla całej grupy, jak i dla porównywanych podgrup. Wśród wszystkich badanych najwyżej nasilone były takie subiektywnie postrzegane stany emocjonalne jak poczucie bezradności, wynikające $\mathrm{z}$ zaistniałej sytuacji, ale i przeświadczenie badanych, że poradzą sobie z edukacją akademicką po wakacjach (średnio ponad 3 punkty na 5 możliwych), a w dalszej kolejności pojawiała się obawa przed zarażeniem się COVID-19 po przywróceniu stacjonarnego nauczania i ogólny poziom stresu (średnio około 2,9 punktu). Najmniej nasilony zaś był deklarowany poziom smutku, wywołany koniecznością powrotu na uczelnię (średnio 2,4 punktu).

W tabeli 2. zawarto ponadto wyniki porównania grup pod względem wyjściowych stanów emocjonalnych. Wykazały one, że badani po zakwalifikowaniu do dwóch podgrup istotnie różnili się pod względem postrzeganego poczucia bezradności $(\mathrm{p}<0,01)$ - wyjściowo wyższa bezradność towarzyszyła studentom, którzy zostali poinformowani o utrzymaniu zdalnej formy kształcenia. Jak wynika z tabeli 1., były to też częściej osoby młodsze oraz studiujące dziennie. Ta grupa przyznawała się także do istotnie wyższego subiektywnego nasilenia smutku, wywołanego samą myślą o powrocie na uczelnię, nawet bez uściślenia formy studiowania $(\mathrm{p}<$ $0,05)$. 
Tabela 2

Statystyki opisowe pierwszego pomiaru stanów emocjonalnych

\begin{tabular}{lccccc}
\hline \multirow{2}{*}{ Zmienne: } & $\begin{array}{c}\text { Cała grupa, } \\
\mathrm{N}=296\end{array}$ & $\begin{array}{c}\text { Nie } \\
\text { wracamy, } \\
\mathrm{n}=147\end{array}$ & $\begin{array}{c}\text { Wracamy, } \\
\mathrm{n}=149\end{array}$ & Porównanie grup \\
\cline { 2 - 6 } & $M(S D)$ & $M(S D)$ & $M(S D)$ & $Z$ & $p$ \\
\hline Stres & $2,89(1,54)$ & $3,03(1,50)$ & $2,76(1,57)$ & $-1,440$ & 0,150 \\
\hline Bezradność & $3,62(1,33)$ & $3,86(1,19)$ & $3,39(1,42)$ & $-2,742$ & 0,006 \\
\hline Bezpieczeństwo & $2,76(1,27)$ & $2,71(1,23)$ & $2,80(1,30)$ & $-0,478$ & 0,633 \\
\hline Lęk & $2,74(1,47)$ & $2,83(1,47)$ & $2,65(1,47)$ & $-1,101$ & 0,271 \\
\hline Pozytywne & $2,81(1,39)$ & $2,93(1,36)$ & $2,69(1,42)$ & $-1,471$ & 0,141 \\
wartościowanie powrotu & & & & & \\
\hline Niepokój & $2,82(1,50)$ & $2,91(1,48)$ & $2,73(1,51)$ & $-1,047$ & 0,295 \\
\hline Smutek & $2,40(1,47)$ & $2,58(1,49)$ & $2,23(1,43)$ & $-2,159$ & 0,031 \\
\hline Obawa przed zarażeniem & $2,92(1,39)$ & $2,97(1,43)$ & $2,86(1,35)$ & $-0,684$ & 0,494 \\
\hline Zaradność po powrocie & $3,10(1,13)$ & $3,14(1,15)$ & $3,07(1,11)$ & $-0,565$ & 0,572 \\
na uczelnię & & & & & \\
\hline
\end{tabular}

Źródło: badanie własne autorów.

W tabeli 3. zawarto wyniki drugiego pomiaru deklarowanych afektów, dokonanego po zaprezentowaniu badanym informacji. Uwzględniono $\mathrm{w}$ nim również różnice między grupami. Odnotowano tylko nie $w$ pełni istotną statystycznie różnicę $\mathrm{w}$ wartościowaniu powrotu na uczelnię jako zdarzenia pozytywnego $(\mathrm{p}<0,1)$, poza utrzymującą się od pierwszego pomiaru przewagą poczucia bezradności $(p<0,01)$ i smutku $(\mathrm{p}<0,5)$.

Tabela 3

Statystyki opisowe drugiego pomiaru stanów emocjonalnych

\begin{tabular}{lccccc}
\hline \multirow{2}{*}{ Zmienne: } & $\begin{array}{c}\text { Cała grupa, } \\
\mathrm{N}=296\end{array}$ & $\begin{array}{c}\text { Nie } \\
\text { wracamy, } \\
\mathrm{n}=147\end{array}$ & $\begin{array}{c}\text { Wracamy, } \\
\mathrm{n}=149\end{array}$ & $\begin{array}{c}\text { Porównanie } \\
\text { grup }\end{array}$ \\
\cline { 2 - 6 } & $M(S D)$ & $M(S D)$ & $M(S D)$ & $Z$ & $p$ \\
\hline Stres & $2,86(1,51)$ & $2,95(1,44)$ & $2,77(1,58)$ & $-0,956$ & 0,339 \\
\hline Bezradność & $3,50(1,40)$ & $3,79(1,21)$ & $3,21(1,51)$ & $-3,154$ & 0,002 \\
\hline Bezpieczeństwo & $2,93(1,30)$ & $2,90(1,22)$ & $2,95(1,38)$ & $-0,272$ & 0,785 \\
\hline Lęk & $2,76(1,50)$ & $2,80(1,44)$ & $2,71(1,56)$ & $-0,551$ & 0,582 \\
\hline $\begin{array}{l}\text { Pozytywne wartościowanie } \\
\text { powrotu na uczelnie }\end{array}$ & $2,80(1,44)$ & $2,94(1,42)$ & $2,66(1,45)$ & $-1,707$ & 0,088 \\
\hline Niepokój & $2,88(1,48)$ & $2,88(1,44)$ & $2,87(1,52)$ & $-0,014$ & 0,989 \\
\hline Smutek & $2,40(1,47)$ & $2,58(1,47)$ & $2,21(1,44)$ & $-2,266$ & 0,023 \\
\hline Obawa przed zarażeniem & $2,88(1,42)$ & $2,85(1,42)$ & $2,91(1,43)$ & $-0,323$ & 0,746 \\
\hline $\begin{array}{l}\text { Zaradność po powrocie na } \\
\text { uczelnie }\end{array}$ & $3,06(1,11)$ & $3,03(1,14)$ & $3,09(1,08)$ & $-0,406$ & 0,685 \\
\hline
\end{tabular}

Źródło: badanie własne autorów. 
Wśród osób poinformowanych, że w najbliższym roku akademickim nie wróca na uczelnię i kontynuowana będzie nauka zdalna, odnotowano istotny wzrost subiektywnego poczucia bezpieczeństwa, średnio o 0,19 punktu $(Z=-2,558 ; p=0,011)$, a pozostałe aspekty subiektywnej oceny pozostały bez istotnych statystycznie zmian. Co ciekawe, wśród studentów powiadomionych o powrocie do nauki stacjonarnej od przyszłego semestru również zaobserwowano istotny wzrost deklarowanego poczucia bezpieczeństwa, średnio o 0,15 punktu $(Z=-2,142 ; p=0,032)$. Jednakże $w$ grupie, której zakomunikowano zakończenie nauki zdalnej zaobserwowano ponadto istotny spadek nasilenia bezradności - średnio o 0,18 punktu $(Z=-2,420 ; p=0,016)$ oraz odczuwanego niepokoju, wywołanego powrotem na uczelnię - średnio o 0,14 punktu ( $Z=$ $-2,046 ; p=0,041)$. Wyniki sugerują zatem, że podanie jakiejkolwiek informacji o przyszłych warunkach studiowania, istotnie zwiększało poczucie bezpieczeństwa, bez względu na to, jakie znaczenie niosła ze sobą podana wiadomość. Z kolei zapowiedź przyszłego powrotu na uczelnię wzbudzała $\mathrm{w}$ studentach ambiwalentne odczucia, z jednej strony deklarowali oni spadek bezradności, ale z drugiej - wzrost niepokoju.

Dodatkowa hipoteza socjodemograficzna odnosiła się do występowania związków wymienionych niżej charakterystyk ze stanami emocjonalnymi badanych. Aby ją zweryfikować, analizie poddano wyniki pierwszego pomiaru afektów dokonanego wśród wszystkich studentów $(\mathrm{N}=296)$. Zgodnie z oczekiwaniami, płeć istotnie różnicowała większość postrzeganych stanów afektywnych. Kobiety cechowały się wyższym subiektywnym odczuciem stresu $(Z=-2,131 ; p=0,033)$, lęku $(Z=-2,748$; $p=0,006)$, niepokoju $(Z=-2,160 ; p=0,031)$, obawą przed zarażeniem $(Z=-3,015$; $p=0,003)$ i trudnościami w nauce $(Z=-2,409 ; p=0,016)$, czuły się także $w$ związku z powrotem na uczelnię mniej bezpiecznie $(Z=-2,197 ; p=0,028)$. Wraz z wiekiem studentów nieznacznie spadało ogólne, deklarowane nasilenie stresu ( $r h o=-0,152$; $p=0,009)$, lęku (rho = -0,179; $p=0,002)$, niepokoju, związanego ze wznowieniem nauki stacjonarnej $(r h o=-0,145 ; p=0,012)$, obaw przed zarażeniem się na uczelni (rho $=-0,156 ; p=0,007)$, smutku (rho $=-0,179 ; p=0,002)$, ale i postrzeganie powrotu na uczelnię jako zdarzenia pozytywnego $(r h o=-0,169 ; p=0,003)$. Należy zaznaczyć, że wszystkie powyższe korelacje są istotne z punktu widzenia statystycznego $(p<0,05)$. Wielkość miejsca zamieszkania nie była powiązana z żadnym z doświadczanych przez badanych stanów emocjonalnych. Im wyższe zmierzone ryzyko zachorowania na COVID-19, dotyczące studentów jak i ich bliskich, tym bardziej negatywny był obraz wszystkich mierzonych aspektów emocjonalnego stosunku do powrotu na uczelnię $(p<0,05)$. Tendencję tę odnotowano również w przypadku drugiej zmiennej, odnoszącej się do chęci wznowienia nauczania stacjonarnego. Wykazano, że studenci, którzy deklarowali znajdowanie się $\mathrm{w}$ grupie podwyższonego ryzyka zarażenia się koronawirusem, preferowali sesję letnią w trybie wyłącznie zdalnym.

\section{DyskusJa}

Jak wskazują wyniki - nie ma jednoznacznej odpowiedzi emocjonalnej studentów na pojawienie się oficjalnego rozporządzenia, dotyczącego terminu powrotu na uczelnię. Sam fakt uzyskania informacji, która pochodziła z rzetelnego źródła, przekładał się na wzrost subiektywnego poczucia bezpieczeństwa. Zostało to spowodowane redukcją niepewności co do przyszłej formy studiowania. Natomiast tylko wśród 
osób powiadomionych o wznowieniu nauczania stacjonarnego, mimo trwającego zagrożenia zdrowotnego, odnotowano korzystny spadek odczuwanej bezradności, ale wraz z niekorzystnym wzrostem deklarowanego niepokoju. Okazuje się, że żadna $\mathrm{z}$ proponowanych $\mathrm{w}$ oświadczeniu dat nie spowodowała obiektywnie pozytywnych lub negatywnych zmian, chociaż tylko wizja zakończenia edukacji zdalnej wywoływała wśród badanych ambiwalentne odczucia. Wyniki te sugerują też, że istnieć może szereg nieujętych w eksperymencie czynników, kształtujących preferencje studentów do kontynuowania nauki w warunkach izolacji, bądź do powrotu do nauczania stacjonarnego. Być może poczucie bezpieczeństwa podczas nauki zdalnej jest również związane z potencjalnie łatwiejszym zaliczaniem egzaminów. Wysunięte przez nas wnioski korespondują z obserwacjami innych badaczy. Wykazano, że strach i stres spowodowany pandemią COVID-19 mogą wywoływać silne reakcje emocjonalne, które finalnie są w stanie doprowadzić do pogorszenia stanu zdrowia. Ponadto, przejście na nauczanie zdalne podwyższa poziom bezradności wśród rozmaitych grup studentów, w zależności od czynników pobocznych. Możliwości osiągania satysfakcjonujących wyników w nauce podczas e-learningu są szczególnie ograniczone w przypadku osób z niskimi umiejętnościami technologicznymi (Ziegler, Gläser-Zikuda, Kopp, Bedenlier, Händel, 2020). Również ogólna satysfakcja ze studiowania może moderować preferencje osób badanych, a wpływają na nią czynniki niezależne od uczących się, jak np. umiejętności dydaktyczne nauczycieli (Rehman, Zaheer, 2010), budowanie w podopiecznych idei odpowiedzialności, współpracy i dyscypliny oraz różnice płciowe czy inne czynniki socjodemograficzne (Hassan, Hossain, Hoq, Islam, Sultana, 2019).

Jak wskazuje Robin Mason i Martin Weller, czynniki podnoszące satysfakcję studentów, którzy biorą udział w kursach internetowych dotyczą również wsparcia ze strony prowadzącego, personelu bądź innych studiujących. Znaczenie ma również przeznaczona na naukę ilość czasu, poziom cierpliwości i motywacji. Oczekiwaniom uczących się powinna odpowiadać też treść i sposób prezentacji materiału (Mason, Weller, 2000).

Zgodnie z badaniami, zarówno dla satysfakcji z życia, jak i poczucia samotności istotna jest częstotliwość kontaktów społecznych (Kosowski, Mróz, 2020). Ograniczenie interakcji rówieśniczych podczas pandemii COVID-19, szczególnie w grupie młodych dorosłych, może skutkować znacznym pogorszeniem się ich samopoczucia psychicznego i negatywnie wpływać na ich umiejętności radzenia sobie ze stresem (Cudo, 2020). Również stopień zadowolenia ze studiów wpływa na dobrostan (Kulawska, 2019). Niewykluczone, że wśród badanych deklarowany wyższy poziom niepokoju wynikał z obiektywnie wyższego ryzyka zarażenia się wirusem, natomiast subiektywny spadek bezradności mógł być związany z powrotem do znanych sprzed pandemii warunków studiowania oraz wizją zwiększenia częstotliwości kontaktów społecznych, której brak prawdopodobnie nasilał bezradność młodych ludzi w warunkach izolacji. Zaś sam fakt przekazania dowolnej informacji, dotyczącej formy kształcenia w październiku 2020 roku, może zwiększać postrzegane poczucie bezpieczeństwa, poprzez redukcję niepewności co do najbliższych miesięcy. Przeprowadzone badanie sugeruje, że po pierwszym semestrze zdalnej nauki ani jej kontynuacja, ani potencjalny powrót na uczelnię nie generowały jasnej odpowiedzi emocjonalnej 
studentów, która świadczyłaby o obiektywnej słuszności któregoś z możliwych wyborów.

\section{SEABE PUNKTY BADANIA}

Uczestnicy badania nie są reprezentatywnym przykładem wszystkich studiujących, ani też tych uczących się zdalnie. Aby wzbogacić ten eksperyment należałoby zadbać o większą różnorodność respondentów pod względem charakterystyk, takich jak: zróżnicowanie województw, typów uczelni czy kierunków studiów. Co więcej, rozkład płci w grupie jest nierówny - charakteryzuje się ona znaczną przewagą kobiet. Ponadto, występuje różnica wieku studentów zakwalifikowanych do puli „wracamy" $i$ „,nie wracamy" na uczelnię, co sprawiło, że obie grupy nie były homogeniczne względem siebie. Jest to znaczące, gdy porównuje się ze sobą zbiory osób badanych. Kolejnym ograniczeniem było niespełnienie znaczącego kryterium eksperymentu, jakim jest kontrola warunków badania oraz czynników zakłócających.

W celu zwiększenia realizmu psychologicznego sytuacji eksperymentalnej zastosowano instrukcję maskującą - uczestnicy nie zostali poinformowani o rzeczywistym celu przeprowadzonego badania, by uniemożliwić rozpoznanie jego kontekstu psychologicznego (Brzeziński, 2004). Przyjmuje się, że każde celowe wprowadzenie badanych w błąd jest zabiegiem uchodzącym za nieetyczny. Dlatego też, aby zniwelować potencjalne zagrożenie dla dobrostanu psychicznego uczestników eksperymentu, w zakończeniu formularza wyeksponowano informację o nieprawdziwości zawartych w nim oświadczeń.

Choć praca ma pewne ograniczenia - zwłaszcza grupę badana, która nie jest w pełni reprezentatywna, a także brak wystandaryzowanych narzędzi - zachęca do kontynuacji badań nad postrzeganiem zdalnego nauczania jako efektywnej formy ochrony studentów przed negatywnymi skutkami COVID-19.

\section{Bibliografia}

[1] Rozporządzenie Ministra Nauki i Szkolnictwa Wyższego z dnia 11 marca 2020 r., Dziennik Ustaw Rzeczypospolitej Polskiej. Pobrane 26.06.2021 z: https://dziennikustaw.gov.pl/D2020000040501.pdf.

[2] Rozporządzenie Ministra Nauki i Szkolnictwa Wyższego z dnia 22 maja 2020 r., Dziennik Ustaw Rzeczypospolitej Polskiej. Pobrane 26.06.2021 z: https://dziennikustaw.gov.pl/D2020000040501.pdf.

[3] Abbasi, S., Ayoob, T., Malik, A., Memon, S. (2020). Perceptions of students regarding E learning during Covid-19 at a private medical college. Pakistan Journal of Medical Sciences, 36 (COVID19-S4), 57-61. DOI: 10.12669/pjms.36.COVID19-S4.2766.

[4] Adarkwah, M. A. (2020). .,I'm not against online teaching, but what about us?": ICT in Ghana post Covid-19. Education and Information Technologies, 26, 1-21. DOI: 10.1007/s10639-020-10331-z.

[5] Adnan, M., Anwar K. (2020) Online learning amid the COVID-19 pandemic: Students perspectives. Journal of Pedagogical Research, 1(2), 45-51.

[6] Bell, D. J., Self, M. M., Davis, C., Conway, F., Washburn, J. J., Crepeau-Hobson, F. (2020). Health service psychology education and training in the time of COVID-19: Challenges and opportunities. American Psychologist, 75(7), 919-932.

[7] Brzeziński, J. (2004). Metodologia badań psychologicznych. Warszawa: Wydawnictwo Naukowe PWN.

[8] Cao, W., Fang, Z., Hou, G., Han, M., Xu, X., Dong, J., Zheng, J. (2020). The psychological impact of the COVID-19 epidemic on college students in China. Psychiatry Research, 287, 112934.

[9] Cudo, A., Gambin, M., Gorgol, J., Hansen, K., Huflejt-Łukasik, M., Kmita, G., Kubicka, K., Łyś, A., Maison, D., Oleksy, T., Sękowski, M., Wnuk, A., Woźniak-Prus, K. (2020). Uwwarunkowania objawów depresji i lęku uogólnionego u dorostych Polaków w trakcie epidemii Covid-19 - raport z pierwszej fali badania podłużnego. Pobrane 26.06 .2021 z: http:// psych.uw.edu.pl/wp-content/uploads/sites/98/2020/05/Uwarunkowania_objawow_depresji_leku_w_trakcie_pandemii_raport.pdf. 
[10] Hasan, N., Bao, Y. (2020). Impact of „e-Learning crack-up” perception on psychological distress among college students during COVID-19 pandemic: A mediating role of "fear of academic year loss." Children and Youth Services Review, 118, 105355.

[11] Hassan, Z., Hossain, M., Hoq, M., Islam, R., Sultana, I. (2019) Determinants of student's satisfaction at higher educational institution in Bangladesh: Evidence from private and public universities, Malaysian Online Journal of Education, 3(1), 49-58.

[12] Händel, M., Stephan, M., Gläser-Zikuda, M., Kopp, B., Bedenlier, S., Ziegler, A. (2020). Digital readiness and its effects on higher education student socio-emotional experiences in the context of COVID-19 pandemic, Journal of Research on Technology in Education. DOI: 10.1080/15391523.2020.1846147.

[13] Huang, Y., Zhao, N. (2020). Generalized anxiety disorder, depressive symptoms and sleep quality during COVID-19 outbreak in China: a web-based cross-sectional survey, Psychiatry Research, 288, 112954.

[14] Kosowski, P., Mróz, J. (2020). Ocena komunikacja poczucie samotności i satysfakcji z życia w czasie pandemii, Kwartalnik Naukowy Fides et Ratio, 42(2), 214-226. DOI: 10.34766/fetr.v42i2.284.

[15] Kulawska, E. (2019). Dobrostan psychiczny a poziom odczuwanego stresu i satysfakcji ze studiów w doświadczeniach studentów pedagogiki przedszkolnej i wczesnoszkolnej, Forum Pedagogiczne, 9(2/2), 129-149. DOI: 10.21697/ fp.2019.2.33.

[16] Mason, R., Weller, M. (2000). Factors affecting students satisfaction on a web course. Australasian Journal of Educational Technology, 16(2). DOI: 10.14742/ajet.1830.

[17] Marelli, S., Castelnuovo, A., Somma, A., Castronovo, A., Mombelli, S., Bottoni, D., Leitner C., Fossati, A., Ferini-Strambi, L. (2020). Impact of COVID-19 lockdown on sleep quality in university students and administration staff, Journal of Neurology. DOI: 10.1007/s00415-020-10056-6.

[18] Mechili, E. A., Saliaj, A., Kamberi, F., Girvalaki, C., Peto, E., Patelarou, A. E., Bucaj, J., Patelarou, E. (2020). Is the mental health of young students and their family members affected during the quarantine period? Evidence from the COVID-19 pandemic in Albania, Journal of Psychiatric and Mental Health Nursing, 28(3), 317-325. DOI: 10.1111/ jpm.12672.

[19] Rehman, K., Zaheer, B. (2010). A study examining the students satisfaction in higher education, Procedia - Social and Behavioral Sciences, 2(2), 2010, 5446-5450. DOI: 10.1016/j.sbspro.2010.03.888.

[20] Yehudai, M., Bender, S., Gritsenko, V., Konstantinov, V., Reznik, A., Isralowit, R. (2020). COVID-19 Fear, Mental Health, and Substance Misuse Conditions Among University Social Work Students in Israel and Russia, International Journal of Mental Health and Addiction, 6, 1-8. DOI: 10.1007/s11469-020-00360-7.

[21] Ziegler, A., Gläser-Zikuda, M., Kopp, B., Bedenlier, S., Händel, M. (2020). Helplessness Among University Students: An Empirical Study Based on a Modified Framework of Implicit Personality Theories. DOI: 10.31234/osf.io/md93x. Pobrane 26.06.2021 z: https://psyarxiv.com/md93x. 